\title{
A decrease in Leu-11a negative lymphocytes in relation to natural killer cell activity in chromate
} workers

\author{
T Tanigawa, S Araki, T Araki, N Minato
}

Early detection of lung cancer in chromate workers has traditionally utilised chest $x$ ray film and sputum cytology and, more recently, bronchofibroscopy. ${ }^{1}$ These methods are effective, however, only after cancer has fully developed. A need exists to develop new approaches to screening lung cancer in its early phases in high risk populations.

Peripheral lymphocytes consist of T cells, B cells, and non- $T$ non-B cells. A major subgroup of non- $T$ non-B cells consists of natural killer (NK) cells, which are measured using anti Leu-11a antibody; Leu-11a positive cells have been shown to represent lymphocytes with NK activity. ${ }^{2}$ Natural killer cells are a subpopulation of lymphocytes capable of lysing a variety of aberrant cells independent of the major histocompatibility complex. In recent years, evidence has accumulated that NK cells have an important role in inhibition of tumourigenesis. ${ }^{34}$ In patients with lung cancer, the function of NK cells has been reported to be impaired but it is not known whether this effect precedes or follows the appearance of clinical disease: nor has the occupational background of these patients been described. ${ }^{56}$ No systemic evaluation of the number or function capacity of NK cells in workers at a high risk for lung cancer has been reported to date. In the present study, we measured the Leu-1 1 a positive and negative lymphocytes as well as the activity of NK cells in chromate workers.

\section{Subjects and methods}

The procedure was explained to all subjects and our study was conducted with their informed consent.

\footnotetext{
Department of Public Health, Faculty of Medicine, University of Tokyo, Hongo, Bunkyo-ku, Tokyo 113 T Tanigawa, S Araki

Center of Occupational Medicine, Tokyo Rosai (Labour Accident) Hospital, Omoriminami Ota-ku Tokyo 143

T Araki

Department of Medicine, Division of Clinical Immunology, Jichi Medical School, 3311 Yakushiji, Minamikawachi, Kawachi-gun, Tochigi 329-04 Japan N Minato
}

The subjects were aged between 53 and 74 (mean 64 years) and comprised 23 retired male chromate production workers who were exposed to chromium for seven to 35 years (mean 22). Nine workers had nasal septum perforation. The control group consisted of 12 healthy male taxi drivers aged 41 to 64 (mean 53 years). A significant difference in age existed between the two groups but no significant relation between NK cell activity and age has been reported within these age ranges in human adults. ${ }^{78}$ No significant difference was found in smoking habits between chromate workers and the control group (mean values of the Brinkman index, 540 and 720 (cigarettes per day $\times$ smoking years, $p>0.05$ )). At the time of the present study, all subjects were free from the signs and symptoms of infection and none used medicine that might affect the immunological analysis.

Peripheral blood mononuclear cells (PBMC) were isolated from heparinised peripheral blood by FicollConray density centrifugation, washed twice with phosphate buffered saline, and resuspended in RPMI 1640 medium supplemented with $10 \%$ fetal calf serum (FCS). The NK cell activity was determined by the ${ }^{51}$ Cromium release assay ${ }^{9}$ using the human chronic myeloid leukaemia derived cell line $\mathrm{K} 562$ as target cells and PBMC as effector cells. The target cells $\left(2 \times 10^{6}\right)$ were labelled with $3.7 \mathrm{MBq}$ of sodium chromate $\left(\mathrm{Na}_{2}{ }^{51} \mathrm{CrO}_{4}\right)$ (New England Nuclear, Boston, MA) for two hours at $37^{\circ} \mathrm{C}$ in humidified $5 \% \mathrm{CO}_{2}$ in air, washed three times, and then resuspended at $1 \times 10^{5} / \mathrm{ml}$ in $10 \%$ FCS-RPMI 1640 medium. Aliquots $(100 \mu \mathrm{l})$ of the target cells were mixed with varying numbers of PBMC in a microculture plate at effector to target $(\mathrm{E}: \mathrm{T})$ ratios of $5: 1,10: 1,20: 1$, and 40:1 in triplicate. The plate was incubated for four hours.

Radioactivity released into the supernatant (X) was then counted by a $\gamma$-counter. Spontaneous (S) ${ }^{51}$ Chromium release was determined by incubating labelled target cells with medium alone and maximal (M) ${ }^{51}$ Chromium with $1 \%$ triton X-100 (Sigma Chemical Co, St Louis, MO). The per cent specific cytolysis was calculated as $(\mathrm{X}-\mathrm{S}) \times 100 /(\mathrm{M}-\mathrm{S})$ $(\%)$. Using the regression equation of these values to 
Numbers of peripheral lymphocytes, Leu-11 a positive cells, lymphocytes, and gross NK cell activity in chromate workers and in controls (median values with ranges in parentheses)

\begin{tabular}{|c|c|c|}
\hline & Chromate workers & Controls \\
\hline $\begin{array}{l}\text { Lymphocytes (No/mm whole blood) } \\
\text { Proportion to leucocytes }(\%) \\
\text { Leu-1 la positive cells (No/mm whole blood) } \\
\text { Proportion to lymphocytes }(\%) \\
\text { NK cell activity: }\end{array}$ & $\begin{array}{c}2100(1200-3400)^{\star \star} \\
33(18-44)^{\star} \\
270(60-1000) \\
10 \cdot 3(3 \cdot 9-42 \cdot 6)^{\star}\end{array}$ & $\begin{array}{c}3300(2000-4500)^{\star \star} \\
41(28-54)^{\star} \\
140(50-550) \\
5 \cdot 1(1 \cdot 7-20 \cdot 9)^{\star}\end{array}$ \\
\hline Gross NK cell activity (lytic unit $/ 10^{7}$ mononuclear cells) & $54 \cdot 9(0 \cdot 2-140)^{\star}$ & $24 \cdot 1(2 \cdot 1-56)^{\star}$ \\
\hline
\end{tabular}

${ }^{\star} \mathrm{p}<0.01 ;{ }^{\star \star} \mathrm{p}<0.001$.

the logarithm of the E:T ratios, one lytic unit (LU) was defined as the number of effector cells required for $33.3 \%$ specific cytolysis of $10^{4}$ target cells $(\mathrm{N})^{10}$; natural killer cell activity in the peripheral blood (gross NK activity) was expressed as $\mathrm{LU} / 10^{7}$ mononuclear cells.

To determine the relative frequency of NK cells, $2 \times 10^{6}$ PBMC were incubated with $15 \mu$ l FITC conjugated monoclonal anti Leu-11a antibody (Becton Dickinson, Mountain View, CA) on ice for 30 minutes, washed twice with RPMI 1640 and resuspended in 10\% FCS-RPMI 1640. All samples
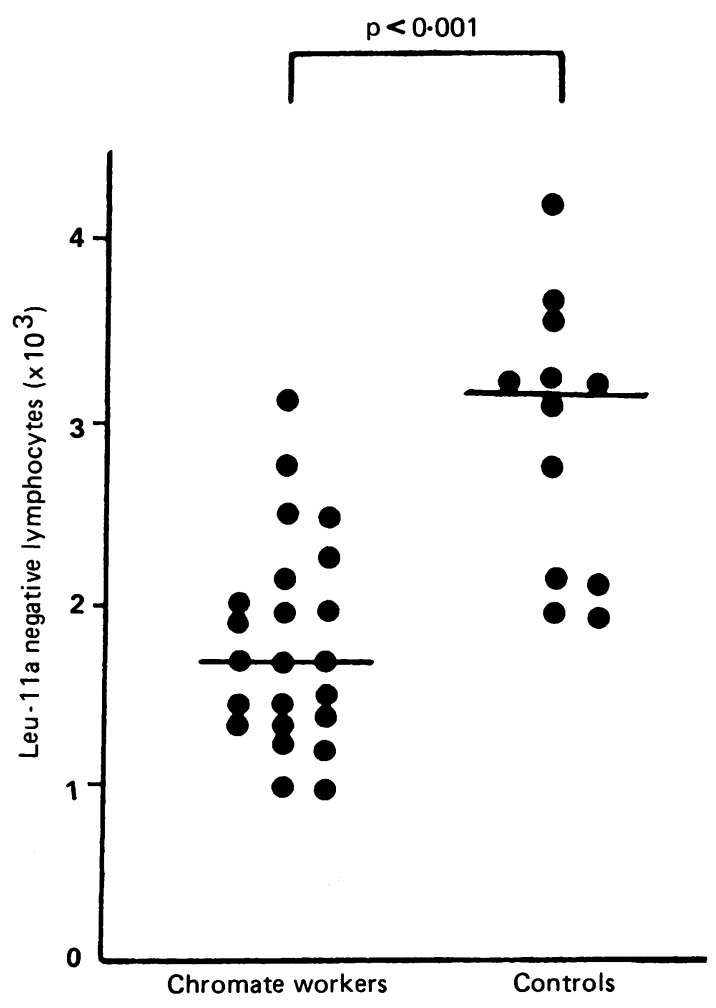

Figure 1 Absolute number of Leu-11 a negative cells in peripheral blood (cells $/ \mathrm{mm}^{3}$ ) in 23 chromate workers and in 12 controls. Transverse lines indicate median values. were then analysed for immunofluorescence on a flow cytometer (EPICS CS, Coulter Electronics, Hialeah, FL). Non-lymphocytic cells contaminating the preparations were excluded from analysis using scatter gates set on the $90^{\circ}$ and straight light scatter profile. Ten thousand lymphocytes were analysed for each sample, and the number of fluorescinated cells were expressed as a percentage of the total lymphocytes. Peripheral blood leucocyte and lymphocyte counts were determined by an automated cell analyser (STKR, Coulter Electronics, Hialeah, FL). To approximate the cytotoxic activity per single NK cell, we defined the "unit NK cell activity" by dividing the gross NK activity by a percentage of Leu-11a positive lymphocytes. All data were analysed statistically by the Wilcoxon rank sum test.

\section{Results}

General haematological examination indicated that chromate workers were lymphocytopenic both absolutely and relatively compared with the control group (table). The proportion of Leu-1la positive cells in peripheral lymphocytes in chromate workers was significantly higher than that in the control group; however, the absolute number of Leu-11a positive cells was not significantly different between the two groups (table). The absolute number of the circulating Leu-1 la negative (non-NK) lymphocytes was significantly decreased in chromate workers (fig 1). No significant difference in unit NK cell activity was found between the two groups (fig 2); the gross NK activity was significantly higher in chromate workers than in the control group (table).

\section{Discussion}

The present study showed a significant decrease in the absolute number of Leu-11a negative lymphocytes without a significant change in the absolute number of Leu-11a positive cells in chromate workers; this indicates lymphocytopenia in the group. These findings, together with no significant change in the unit NK cell activity, account for the increased gross NK activity in chromate workers. The mechanism responsible for the decrease in the Leu-1 la negative lymphocytes should be clarified by further studies. 


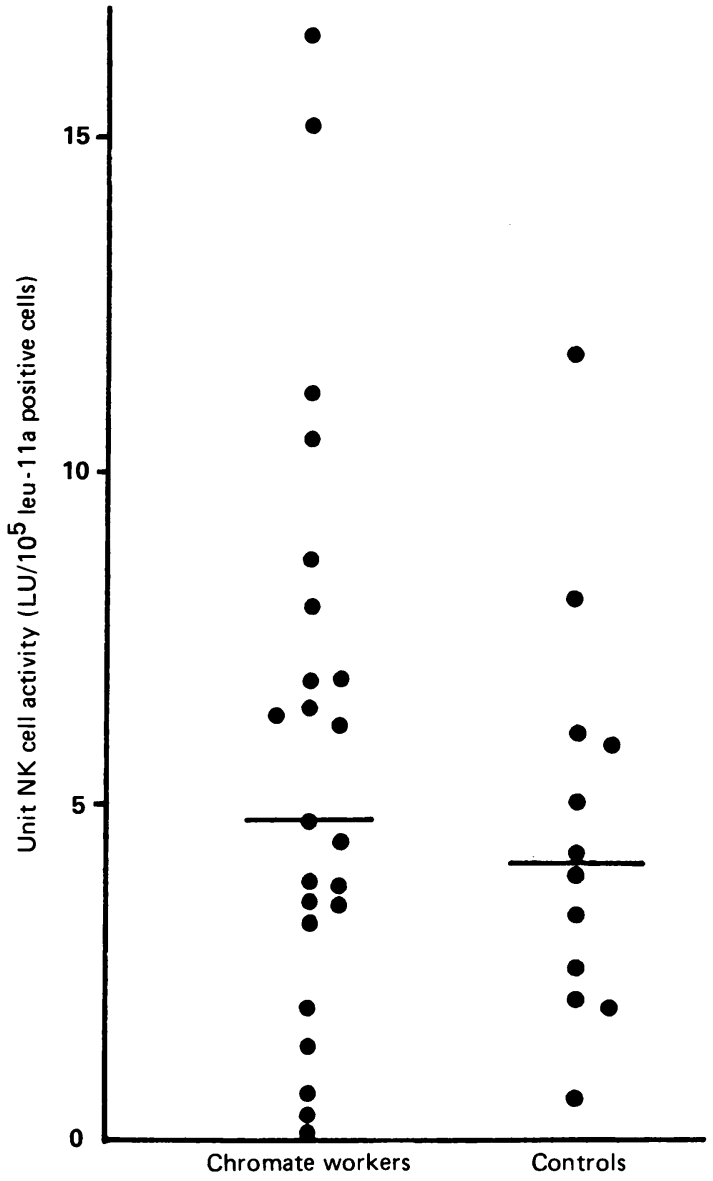

Figure 2 Unit natural killer (NK) cell activity in 23 chromate workers and in 12 controls. Transverse lines indicate median values.

Kimber et al reported that chronic low level exposure to inorganic lead in man did not affect gross NK activity. ${ }^{11}$ We have recently reported that unit NK cell activity was significantly decreased in workers exposed to aromatic amines. ${ }^{12}$ On the other hand, there are some reports on the inhibitory effects of zinc ${ }^{13}$ and nickel ${ }^{14}$ on murine NK activity. Further studies of unit NK cell activity and the absolute number of NK and non-NK cells are essential.

In a practical sense, measurement of the proportion of circulating Leu-1la negative cells may provide a useful index to reflect immunological alterations in chromate workers. This method also has advantages in that the proportion can be quantitatively and reproducibly determined and does not require a sensitive bioassay.

In conclusion, it is suggested that the absolute number of circulating Leu-1 la negative (non-NK) lymphocytes are decreased in chromate workers. The measurement of the lymphocyte subpopulation may provide a useful indicator of the effects of exposure of chromium in man. Results of a follow up study for the present group of workers will be reported.

We are grateful to Professor P J Landrigan, Mt Sinai School of Medicine for his review of this manuscript and to Ms S Kinjo for helping with blood collection.

Requests for reprints to: Professor S Araki, Department of Public Health, Faculty of Medicine, University of Tokyo, Hongo, Bunkyo-ku, Tokyo 113, Japan.

1 Araki $\mathrm{T}$, Ushio $\mathrm{K}$, Takeuchi $\mathrm{Y}$, et al. The usefulness of bronchoscopy in early detection of lung cancer among chromate workers. Japanese Journal of Traumatology and Occupational Medicine 1987;35:705-9. (In Japanese.)

2 Lanier LL, Le AM, Phillips JH, Warner NL, Babcock GF. Subpopulations of human natural killer cells defined by expression of the Leu-7 (HNK-1) and Leu-11 (NK-15) antigens. J Immunol 1983;131:1789-96.

3 Bloom BR. Natural killers to rescue immune surveillance? Nature 1982;18:214-5.

4 Minato N. Natural killer cells: characteristics and their role in anti-tumor resistance. In: Hashimoto $\mathrm{Y}$, Hamaoka $\mathrm{T}$, eds. Gann monograph on cancer research. No 34: Celluar and molecular mechanisms of tumor immunity. Tokyo: Japan scientific societies press, 1988:99-110.

5 Phillips B, Marshall ME, Brown S, Thompson JS. Effect of smoking on human natural killer cell activity. Cancer 1985;56:2789-92.

6 Ching CL, Yuh CK, Wen $\mathrm{CH}$, Ching YL. Natural killer activity in lung cancer patients. Chest 1987;92:1022-4.

7 Onsrud $M$. Age dependent changes in some human lymphocyte sub-populations. Acta Pathol Microbiol Immunol Scand C $1981 ; 89: 55-62$.

8 Herberman RB, Holden HT. Natural cell-mediated immunity. Adv Cancer Res 1978;27:305-77.

9 Minato N, Takeda A, Kano S, Takaku F. Studies of the functions of natural killer-interferon system in patients with Sjögren syndrome. J Clin Invest 1982;69:581-8.

10 Cerottini JC, Brunner KT. In vitro assay of target cell lysis by sensitized lymphocytes. In: Bloom BR, Glade PR, eds. In vitro methods in cell-mediated immunity. New York and London: Academic Press, 1971:369-73.

11 Kimber I, Stonard MD, Gidlow DA, Niewola Z. Influence of chronic low-level exposure to lead on plasma immunoglobulin concentration and cellular immune function in man. Int Arch Occup Environ Health 1986;57:117-25.

12 Tanigawa T, Araki S, Ishizu S, Morita T, Okazaki H, Minato N. Natural killer cell activity in workers exposed to benzidine and beta-naphthylamine. Br J Ind Med 1990;47:338-41.

13 Stephenson RA, Luft BJ, Pedrotti PW, Remington JS. Inhibition of mouse natural killer cell activity by zinc. J Nat Cancer Inst 1985;74:1067-70.

14 Smialowicz RJ, Rogers RR, Riddle MM, et al. Immunologic effects of nickel II. Suppression of natural killer cell activity. Environ Res 1985;36:56-66.

Accepted 29 August 1990 